\title{
The Greek Conundrum
}

\author{
Vassilis K. Fouskas
}

\section{Introduction}

In the European election held on 26 May 2019, Syriza scored very poorly: $23,76 \%$ of the vote as opposed to $33,12 \%$ of its main rival, the right-wing New Democracy party. Because of this, and fearing a devastating defeat had he let parliamentary elections to take place upon expiration of his term in office in October 2019, Alexis Tsipras, the country's PM and Syriza's leader, announced a national ballot for the $7^{\text {th }}$ of July. Moreover, a little less than a month before the national election date, the country's official statistical service, ELSTAT, published some interesting data comparing and contrasting the periods of austerity between 2015-18 during the Syriza cabinets, and 2010-15, the period of centrist coalition governments that absorbed two bailout agreements.' Under Syriza's term, defined by a third bailout, the rate of impoverishment of Greek society - what ELSTAT calls "material deprivation" - was $20,4 \%$, whereas during the period of coalition governments the rate was $19,1 \%$. Thus, many thought that Syriza is heading towards a major crush in the national ballot of July.

But Syriza did not crush. Tsipras's party, which was forced to rule during most of its term in office together with the nationalist party of Independent Greeks, held its ground receiving just under $32 \%$ of the vote. New Democracy stood at under $40 \%$ and has now an absolute majority of $158 \mathrm{MPs}$ in a parliament of 300 legislators, so there is no need for support from any other minor party in order to govern. The Syriza vote share was down only $3,5 \%$ from the last parliamentary election of September 2015, but the New Democracy share rose from $28 \%$ to nearly $40 \%$. The difficulty, in this respect, is not so much to explain why Syriza lost, but why it did not crush, having pursued an unbelievably harsh austerity programme, which was embedded in the third bail-out agreement signed in July 2015.i This, it should be remembered, caused a major split in the party, losing dozens of its MPs, as well as several ministers and deputy ministers. Today, Syriza, with the exception of the British Labour Party, is perhaps the best electoral performer among the parties of the European centre-left.

Why this shift to the right and why did Syriza not crush? This is what I call here "the Greek conundrum", for which I will try to provide a convincing answer.

\section{Consolidation of a new two-party (state) system}

Think of a plane that flies at 10,000 feet. Suddenly, the plane goes through massive turbulence, stalls and then begins losing altitude, almost a free fall. After massive effort by the pilots who, one after the other, are trying to arrest its dive, in the end the plane stabilises at a much lower altitude, around 1,000 feet. During all this time of turbulence and free fall, the passengers panicked and began screaming. The advice the pilots get from the nearest airport's control tower is that this altitude is not sustainable and that if the plane continues to fly at that level, soon or later, will crush. At the same time, they suggest to the pilots not to communicate any disturbing information to their passengers because the worst thing that can happen is to have them screaming at a time when they must concentrate on how to save the plane and everybody's life. By and large, the political and economic situation in Greece today can be explained with the adventure of this plane, its passengers and pilots. 
In less than eight years, Greece lost nearly $25 \%$ of its GDP, what a country usually loses in times of war - sharp loss of the plane's altitude. The massive austerity ensued, radicalised large swaths of the population, pauperised the labouring classes, eroded the privileges of the middle class and forced hundreds of thousands to emigrate - the passengers began screaming non-stop. Syriza rose to political prominence by capitalising on social radicalism, which demanded an end to the regime of austerity imposed on Greece by its creditors. Syriza assumed office in January 2015, promising to stop austerity and get the country outside the humiliating straightjacket of the bailout agreements - in effect, starting to recuperate the plane's 10,000 feet altitude. It did not do that. In fact, as we saw earlier, the impoverishment of the Greeks continued unabated, whereas the country's debt remains at the level it was in 2010, roughly at $180 \%$ of the GDP - so the plane continued to fly at 1,000 feet. But with Syriza in charge - on the pilot's seat - society's radicalism, all of a sudden, was defused - the passengers stopped screaming. Under Syriza, civil society came to terms with the conditions of austerity as an inevitable trait of their everyday life - they got used to the low altitude since there was no really any other pilot to try: There is No Alternative (TINA). Brushing aside calls from the IMF and prominent economists, such as Paul Krugman and Joseph Stiglitz - in our metaphor, the nearest airport's control tower that Greece's debt is unsustainable and the bailout agreements offer no way out of the debt-trap, Syriza continued to implement the creditors' programme. But it avoided communicating this type of messages to the passengers. Instead, having the consent of the previous pilots - all major pro-bailout parties voted in favour of the third bailout programme in 2015 - Syriza alleviated the fear and convinced the passengers that Greece can make it: the plane will not crush. In 2018, Tsipras claimed that Greece fulfilled all its targets and the country is back to the markets where it can borrow at a relatively low interest rate. On the foreign policy front, too, Tsipras claimed victory by way of having agreed a new name for Greece's northern neighbour: Republic of North Macedonia - instead of Republic of Macedonia (Macedonia is the name of Greece's northern province bordering with the new Republic).

That is how Syriza brought about the "normalisation" of political life in Greece after the upheaval of the 2010-2015 period. New Democracy and Syriza are now the main pillars of the new two-party system in Greece, replacing the post-1974 two-party system centred on New Democracy and PASOK (Panhellenic Socialist Movement). Other parties that entered parliament surpassing the $3 \%$ threshold include "The Movement for Change" (KINAL), which is the re-branded version of PASOK obtaining 7,9\%; the Greek Communist Party (KKE), the far-right "Greek Solution", and the DiEM25 movement of former Syriza Finance Minister, Yanis Varoufakis, rounded out the list of parties entering parliament with $5.4 \%, 3.8 \%$ and $3.5 \%$ respectively. Golden Dawn, an awkward pro-Nazi party did not make it to parliament, although no doubt many of its voters went to either New Democracy or the new far-right party of "Greek Solution". Euro-sceptic anti-austerity parties of the Left, such as Popular Unity (LAE) and Course to Freedom, both of which originated from Syriza after the split of summer 2015 , did not reach the required $3 \%$. The extreme Left remains deeply fragmented and divided.

What accounts for Syriza's defeat and, at the same time, success? Part of the answer has been insinuated above. Syriza's ruling group, although it won the election of January 2015 on an anti-austerity ticket, it came to grips with the ordoliberal reality of Europe's institutional settings, and accepted austerity.iii Its leading group, whose mixed provenance from KKE, PASOK and Greece's small Euro-communist party could hardly be praised for cohesion, considered that the costs of taking the country outside the single currency and perhaps the EU far outweigh the costs of staying in the club. No doubt, and given the tension with Turkey over Cyprus and the Aegean, they should 
have also factored in what exit from the Eurozone would have meant for the country's position in NATO and other international organisations led by the USA. In this context, Syriza's major contribution to stability, which came at a cost of an equally harsh austerity, was the de-radicalisation of civil society putting a break to any anti-bailout demand it articulated over the course of more than five years. In 2015, Syriza absorbed a large chunk of PASOK and KKE votes and also a small but significant part of New Democracy's voting bloc. In July 2019, Syriza seemed to have lost only the 2015 rightwing bloc of votes that swung back to New Democracy, while holding onto its centreleft electoral base gained mainly from PASOK. Syriza lost because this volatile bloc of voters returned to its ideological right-wing matrix as soon as they became convinced that Syriza offers nothing radically new for Greece other than what New Democracy can offer and deliver even in a more efficient way. A commonly held perception among Greeks is that Syriza is forced to implement neo-liberal austerity measures that are against its statist-socialist ideology and, because of this, it does so badly; whereas with the party of New Democracy in charge "you know what you get and what to expect" and, because there is no opposition between ideology and policy, New Democracy is a better fit for office. Thus, by de-radicalising the people in the wake of accepting austerity, Syriza laid the ground to New Democracy to return to power. This the key reason that led Syriza to defeat.

But, having pursued the same and even harsher austerity policy, why did New Democracy not win by a landslide or, put it another way, why did the Syriza bloc not disintegrate furnishing votes the anti-bailout Left? To answer this question, we need to look at the relationship between Syriza and the state machine during Syriza's term in office.

Syriza had had no experience of government. His only senior member with such experience was former KKE member, Yianis Dragassakis, who took part in the coalition governments of the 1989-90. However, during the 2011-2015 period, many senior PASOK members joined Syriza and assumed ministerial positions soon after Syriza came to power in January 2015. This simple description does not only reflect preferences of personalities or political deals in exchange of votes and loyalties; it reveals an inscription of political technology and know-how of the entire state apparatus which was now replenished with PASOK expertise and Syriza loyalties. Meanwhile, the official ideology of Syriza as expressed by many of its intellectuals in newspapers such as the Ef Syn, was that of right-wing Euro-communism, namely, that the changing of the relationship of forces in favour of the subaltern classes can only take place within the state. ${ }^{i v}$ However, this did not happen and no change of the relationship of forces in favour of the poor and the deprived took place during Syriza's term in office.

Yianis Mauris, Director of Public Issue and one of the sharpest commentators on Greece's party system, showed how Syriza, in just under five years, was transformed from a social movement into a "cartel-party" - the terminology belongs to Peter Mair and other political scientists - completely absorbed by Greece's state apparatus via senior-and-medium rank appointments in ministries, local government, education, media complexes, public corporations and so on. ${ }^{v}$ This is a new form of clientelism. It does not directly connect to the people exchanging favours (such as offering employment in the public sector) with votes. It is a form of clientelism embedded in neo-liberal policy-making in which senior party personnel consolidates its position in key ministries and local government but without, as in the past, preserving any direct clientelistic link with civil society. Eventually, an elite antagonism is formed between the new (left-wing) administrative elite and the old (right-wing) one, an antagonism which is taking place within the state institutions and far-off from society and societal needs. Old-fashioned clientelism was more attuned to the needs of society as, 
effectively, it was exchanging votes for jobs in the public sector, preventing unemployment from getting out of control (Greece never had a strong private sector and developed, large-scale industry). Mauris points out that whereas the constitution of Syriza asserts the political and organisational separation of the party from the state in case Syriza comes to power, what happened in practice was the exact opposite. In particular, whereas article 7 of the Syriza Constitution states that no more than $25 \%$ of the party's post-holders can be employed in senior government jobs, in practice more than $68 \%$ of the party's 151-member Central Committee members enjoy senior government positions. In Syriza's short history, whether in government or in opposition, neither the party apparatus nor the Central Committee of the party branches as "centres of power" had ever had any major say in the drafting of the party's policy. The real power has always been in the hands of a handful of people around Alexis Tsipras and Yianis Dragassakis. In this respect, if compared to PASOK in the first half of the 1980s under the charismatic leadership of Andreas G. Papandreou, PASOK looks more democratic as Papandreou was more inclusive in allowing participation of his senior members in the party's decision-making. In terms of membership, Syriza in late 2015 recorded circa 28,000 out of a voting bloc of just under 2,000,000 people who voted for Syriza. Once in power, the swallowing up of Syriza from the state machine took extraordinary proportions, effectively dismantling Syriza as an organised party, its cohesion being entirely dependent on the cohesion of the Greek state. This is exactly the position the party of New Democracy enjoys, as well as other parties, such as KINAL, which has been displaced by Syriza in senior administrative posts. In this respect, and given that both New Democracy and PASOK (KINAL) voted in favour of the third bailout agreement under Syriza, I would agree with Mauris that the political core of the Greek state is defined by a single party-state with two-three "opposing factions" attributing a façade of democracy in an, otherwise, desperate social situation. This is the meaning I would attribute to Greece's new two-party (state) system.

\section{New Democracy in office}

My analysis so far indicates that New Democracy, Syriza and the ever-present PASOK that was renamed into KINAL, have begun to amalgamate a new government bloc drawing power from Brussels and legitimacy from the Greek people by convincing the Greeks that There Is No Alternative (TINA). This locks out the people from the centres of governmental power and any resistance to Brussels-led austerity becomes impossible. The austerity has enduring features and the major pro-bailout parties need to make sure that people cannot project their interests onto the power-centres. Thus, given the fragmentation of the anti-bailout Left - the Popular Unity party, the Course to Freedom and the Diem25 - there will be a certain stabilisation of a two-party system managing a dilapidated state machine in a political environment constrained not by popular interests and old-fashioned clientelism but by Brussels-imposed austerity.

Having said this, what is to be expected from New Democracy and its new Harvard University educated leader, Kyriakos Mitsotakis - son of a well-known Greek political family? Will matters improve under his right-wing cabinet? No. New Democracy will honour the country's international obligations, that is first and foremost, the commitment to having Greece under a permanent primary surplus until 2060; intensify the layoffs in the public sector - starting with the country's electricity grid - and deepen the medieval regime in industrial relations brought about by the austerity of the bailout agreements. This, of course, will have a number of side-effects, including the continuation of migration abroad and the fall in the birth-rate - more than 400,000 Greeks under 40 years old emigrated over the last ten years. Certainly, there is room for reducing the high level of taxation imposed by the lenders via Syriza, something which will keep the popularity of the current Greek PM, Kyriakos Mitsotakis, afloat, while trying to attract foreign capital to invest in Greece. Nevertheless, the fact of the 
matter is that, today, Greece looks more like its Balkan neighbours than a Western European country. Greece does not seem to be converging with the core of Europe but with its Balkan neighbours. Greece's minimum wage of 400 Euros per month is equal to Bosnia's average wage, yet the living daily costs in Greece are much higher than in Bosnia.

\section{Concluding remarks}

In this brief article, I have tried to show that Syriza is chiefly responsible for the return of New Democracy in power. But its defeat in the election of last July was anything but a catastrophe. Syriza's party elites managed to appropriate as best as they could Greece's state machine establishing caucuses of power, influence and clientele in it. What provided cohesion for Syriza's ideologically heterogeneous aggregation, was the Greek state and the governance expertise offered by PASOK's senior members. Syriza managed to rule Greece with the apparatus and elite members of PASOK, which was alternating in power together with New Democracy for more than 40 years since 1974. This was blended with the ideology and certain political ideas of right-wing Eurocommunism, although the real policy context is that of (neo-liberal/ordoliberal) austerity dictated by Brussels. It is this ideological mix that provided legitimacy, as well as the fusion between the party elite and the state that consolidated Syriza and Greece's centre-left in a society that is mesmerised by the dream of a European prosperity, national security and growth that still have to be experienced. As we have argued, Greece's economy is converging towards its Balkan neighbours than other core European economies. All in all, the Greek conundrum can be explained by resorting to an analysis of Syriza and its relationship with the Greek state machine during its four years and six months in office.

\footnotetext{
${ }^{i}$ See, ELSTAT, http://www.statistics.gr/el/statistics (accessed: 8 July 2019)

${ }^{\text {ii }}$ For an overview of the Greek debt crisis and the rise of Syriza to prominence, see: Vassilis K. Fouskas and Constantine Dimoulas, "The Greek workshop of debt and the failure of the European project", Journal of Balkan and Near Eastern Studies, v.14, n.1, March 2012, pp.1-31; Vassilis K. Fouskas and Constantine Dimoulas, Greece, Financialisation and the EU, London and New York, Palgrave, 2013;
} 
Vassilis K. Fouskas, "Letter from Athens", The Political Quarterly, v.86, n.3, July-September 2015, pp.353-59.

iii On the concept of "ordoliberalism" and its overlapping meanings with that of "neo-liberalism", see, Vassilis K. Fouskas and Shampa Roy-Mukherjee, "Neo-liberalism and ordoliberalism. One of two critiques? An Introduction”, Critical Sociology, v.46, n.6, Nov 2019, pp.1-13.

iv This view draws from some aspects of the late Nicos Poulantzas' work in his last theoretical statement, State, Power, Socialism - originally published in French in 1978. However, Poulantzas was not an admirer of right-wing Euro-communism. See especially, Vassilis K. Fouskas, Italy, Europe and the Left. The Transformation of Italian Communism and the European Imperative, Ashgate, Aldershot 1998 and 2019.

" See, Yiannis Mauris, "Syriza, party, state. What after more than four years in office?" (13 June 2019, in Greek), http://www.mavris.gr/6019/syriza-party-state/ (accessed: 13 June 2019) 